\title{
O I Fórum Nacional de Saúde Ocular
}

\author{
Harley E. A. Bicas
}

Nunca se viu, antes, algo parecido. Assim foi o chamado I Fórum Nacional de Saúde Ocular, realizado em Brasília nos dias 30 e 31 de maio deste ano, organizado conjuntamente pelo C.B.O. e pelo Senado Federal, quando esta instituição da República recebeu uma grande comitiva de oftalmologistas brasileiros. Sem ser especificamente um Congresso de Oftalmologia, reuniu expoentes em cada uma de suas múltiplas áreas de conhecimento. Sem ter propositalmente mensagens de ensino, sintetizou pedagogicamente o que de melhor existe na Oftalmologia brasileira em suas relações com a sociedade; e sem buscar qualquer reivindicação política aos senhores senadores e deputados da República, promoveu uma claríssima demonstração da pujança de nossa especialidade, conduzida e administrada por nosso Conselho Brasileiro de Oftalmologia.

Mas permeando todas as reuniões, objetivou-se o esforço para a concretização e elevação dos padrões de saúde ocular e visual de nossos conterrâneos. Um decidido compromisso com o resgatar da cidadania, no que ela possui de mais amplo, pela mão de quem tem, estendida aos menos aquinhoados de nosso sistema; pela orientação de quem usufruiu aprendizagens, aos desamparados do ensino; pela colaboração de quem aprendeu a curar, com os que nem sequer sabem onde e como procurar assistência. Apenas com os títulos dos chamados "blocos" da apresentação pode-se chegar à idéia da magnitude e abrangência do que se procurou, ambicionadamente: Oftalmologia e Saúde Coletiva
(I), Causas prevalentes de cegueira no Brasil (II), A importância das ações inter-institucionais na prevenção da cegueira (III), O deficiente visual no Brasil, reabilitação e inserção social (IV), Exercício profissional da Oftalmologia (V), A contribuição do Comércio e da Indústria (VI), Ações do Ministério da Saúde (VII), Ensino e Pesquisa (VIII), Estágio atual e perspectivas tecnológicas da Oftalmologia brasileira (IX), Conclusões, Propostas e Encaminhamentos (X). Uma temática de riquíssimo conteúdo e de alcance ainda insuspeitado, se todos os benefícios que houverem sido sonhados realizem-se.

A organização desse encontro, altamente prestigiado pela presença de Ministros de Estado, Senadores, Deputados Federais e outras eminentes autoridades de nossa Federação nacional, dá a medida do planejamento, do esforço e da capacidade de sua concretização com que toda a Diretoria do C.B.O. e seus membros, sob a liderança do inspirado presidente Marcos Ávila, enobrecem a oftalmologia brasileira. No centro do poder decisório do país, deu gosto ouvir muito comentados e sobretudo elogiados os projetos e planos nacionais de atendimento à população, já desenvolvidos e em andamento, conduzidos pelo C.B.O.

São com iniciativas desse tipo que se constrói o futuro de uma nação e se engrandece a auto-estima de um povo. Estamos de parabéns. O importante, agora, é mostrar que todas essas capacitações e idéias, estão postas a serviço, não são meros artifícios ou encenações.

\section{Novidades na Internet!!!}

Agora no site CBO você tem disponível todas as informações na íntegra dos

Arquivos Brasileiros de Oftalmologia

http://www.cbo.com.br/abo 